Kawsay Vida 



\section{Kawsay Vida}

\section{A MULTimedia ouechua COURSE FOR BEGINNERS AND Beyond}

\section{By ROSALEEN HOWARD}

With contributions by

Philjimmieson,

Pedro Plaza,

Julieta Zurita,

Rufino Chuquimamani,

Carmen Alosilla,

and Phil Russell
Course Book and Interactive Multimedia DVD

4 University of Texas Press 


\section{רich RECOVERING \\ HA LANGUAGES\&LITERACIES OF THE AMERICAS}

This book is published as part of the Recovering Languages and Literacies of the Americas initiative. Recovering Languages and Literacies is generously supported by the Andrew W. Mellon Foundation.

The royalties from the sale of Kawsay Vida will be used to fund educational and linguistic initiatives among the communities in Bolivia and Peru who collaborated in the project.

The Interactive Multimedia DVD enclosed with this book was produced by the author. The University of Texas Press is not responsible for its contents.

Copyright (๑) 2013 by the University of Texas Press

All rights reserved

Printed in the United States of America

First edition, 2013

Requests for permission to reproduce material from this work should

be sent to:

Permissions

University of Texas Press

P.O. Box 7819

Austin, TX 78713-7819

http://utpress.utexas.edu/index.php/rp-form

( ) The paper used in this book meets the minimum requirements of ANSI/NISO Z39.48-1992 (R1997) (Permanence of Paper).

Library of Congress Cataloging-in-Publication Data

Howard, Rosaleen.

Kawsay Vida : a multimedia Quechua course for beginners and beyond : course book and interactive multimedia dvd / By Rosaleen Howard ; With contributions by Phil Jimmieson, Pedro Plaza, Julieta Zurita, Rufino

Chuquimamani, Carmen Alosilla, and Phil Russell. — 1st ed.

audio disc: digital,CD audio; $4 \frac{3}{4}$ in.

Includes bibliographical references and index.

ISBN 978-0-292-75624-3 (cloth : alk. paper) — ISBN 978-0-292-75444-7

(pbk. : alk. paper)

1. Quechua language-Textbooks for foreign speakers. 2. Quechua language - Grammar. 3. Quechua language - Sound recordings for foreign speakers. I. Title.

PM6303.H69 2014

$498 \cdot .32382421-\mathrm{dc} 23$

doi:10.7560/754447 
This work is dedicated to the many people who have shared their knowledge of the Quechua language with me over many years; and to my family and friends Ǫhichwa yachachiqniykunapaqpis ayllu masiykunapaqpis 
